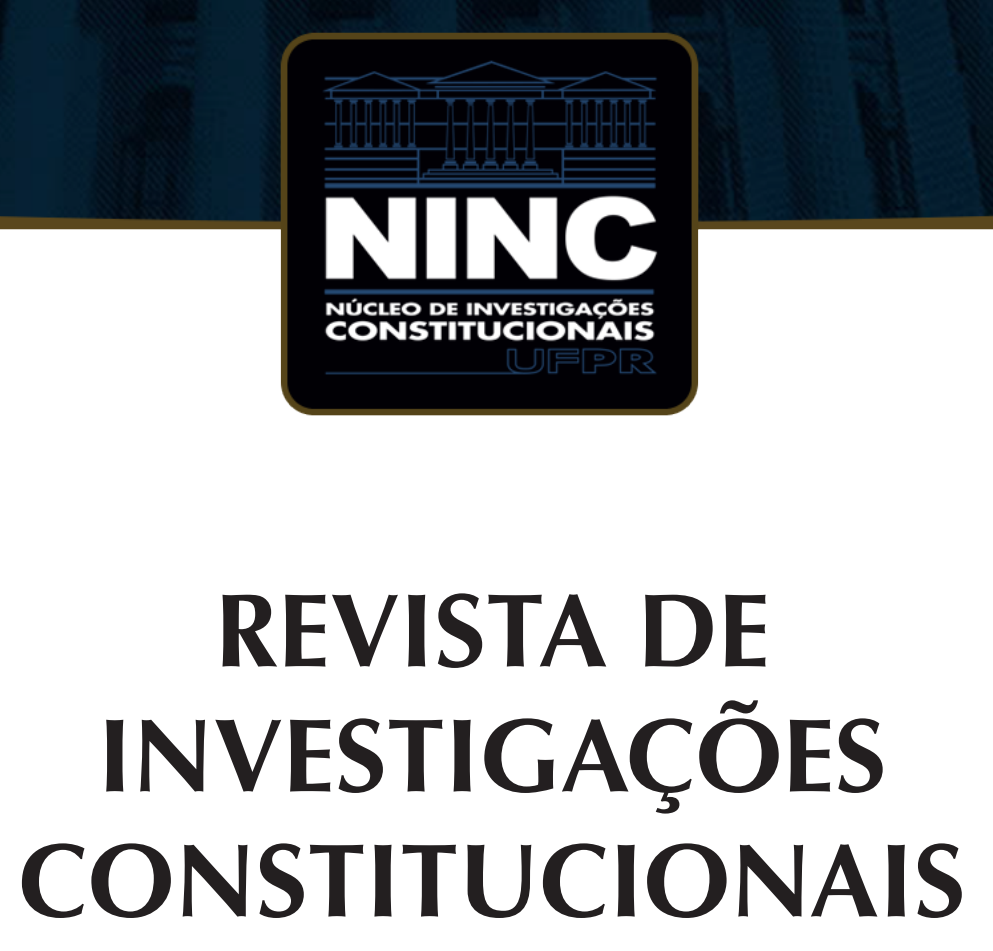

JOURNAL OF CONSTITUTIONAL RESEARCH

vol. 5 | n. 1 | janeiro/abril 2018 | ISSN 2359-5639 | Periodicidade quadrimestral Curitiba | Núcleo de Investigações Constitucionais da UFPR | www.ninc.com.br 


\title{
Separação de poderes e diálogos institucionais nos litígios envolvendo o direito à saúde
}

\section{Separation of powers and institutional dialogues in health litigation}

\author{
ANA PAULA OLIVEIRA ÁVILA* \\ UniRitter - Centro Univesitário Ritter dos Reis (Brasil) \\ http://orcid.org/0000-0001-5430-3099 \\ anapaula.avila@icloud.com
}

KAREN CRISTINA CORREA DE MELO**

UniRitter - Centro Univesitário Ritter dos Reis (Brasil) mandarparakaren@gmail.com

Recebido/Received: 30.08.2017 / August 30th, 2017 Aprovado/Approved: 30.12.2017 / December 30th, 2017

\section{Resumo}

O presente estudo, de natureza interdisciplinar, foi conduzido por profissionais da área do direito e da saúde e tem por objetivo analisar a judicialização do direito à saúde pela perspectiva do necessário diálogo institucional. Empregou-se o método de revisão bibliográfica, documental e jurisprudencial, além observação empírica de práticas adotadas em alguns municípios - em todo caso documentadas em fontes de acesso público. O estudo identifica a enorme complexidade da área da saúde para demonstrar sua característica policêntrica e desnudar todos os interesses que atuam neste mercado econômico (pacientes, médicos, laboratórios farmacêuticos, advogados, ONGs e

\section{Abstract}

The present study, of an interdisciplinary nature, was carried on by professionals from both areas of law and health and aims at analyzing the judicialization of the right to health provisions, from the perspective of the needed institutional dialogue. The methods of bibliographic, documental and jurisprudential review were employed, besides the empirical observation over practices adopted in some municipalities - in every case, documented on public access sources. It begins by identifying the enormous complexity of the area, uncovering all the acting interests on the health market by numerous players (patients, doctors, pharmaceutical laboratories, lawyers, NGOs and

Como citar esse artigo/How to cite this article: AVILA, Ana Paula Oliveira; MELO, Karen Cristina Correa de. Separação de poderes e diálogos institucionais nos litígios envolvendo o direito à saúde. Revista de Investigações Constitucionais, Curitiba, vol. 5, n. 1, p. 83-108, jan./abr. 2018. DOI: 10.5380/rinc.v5i1.54934.

"Professora Titular de Direito Constitucional dos Cursos de Graduação em Direito e Mestrado em Direitos Humanos do UniRitter (Porto Alegre, RS, Brasil). Doutora em Direito Público pela UFRGS (Porto Alegre, RS, Brasil). Mestrado em Direito Público pela UFRGS. E-mail: anapaula.avila@icloud.com.

** Mestranda no Programa de Mestrado em Direitos Humanos do UniRitter (Porto Alegre, RS, Brasil). Bacharel em Direito pelo UniRitter (Brasil). Médica formada pela Universidade Federal do Rio Grande do Sul - UFRGS. Médica Especialista Concursada da Secretaria Municipal de Saúde de Porto Alegre. E-mail: mandarparakaren@gmail.com. 
agentes reguladores) e situando a atividade do Judiciário em face desse complexo quadro. Em seguida, descreve-se como a teoria do diálogo institucional deixou o campo da abstração teórica para operar na prática, por meio da interação dos diversos órgãos responsáveis pela recuperação e promoção da saúde. Conclui-se pela transformação procedimental operada nos litígios envolvendo o direito à saúde e a importância das formas de comunicação interinstitucional para a democracia.

Palavras-chave: saúde; medicamentos; judicialização; diálogo institucional; Supremo Tribunal Federal. regulatory agents) and positioning the Judiciary activity in this complex picture. Following, it describes how the institutional dialogue leaves theoretical abstractions to operate in practical ways, through the interaction of several entities that are responsible for the recovery and promotion of health. In conclusion, we point the procedural transformation operated on health litigation, which involve the right to health and the relevance of inter-institutional communication to democracy.

Keywords: health care; litigation; institutional dialogue; Brazilian Supreme Court.

\section{SUMÁRIO}

1. Considerações Iniciais; 2. A Complexidade da Saúde Humana: Médicos, Indústrias Farmacêuticas, Advogados e ONGs. 3. A atuação do Poder Judiciário no complexo quadro da saúde. 4. O Desenho Institucional para uma realidade complexa. 5. Considerações finais; 6 . Referências.

"Querer o bem com demais força, de incerto jeito, pode já estar sendo se querendo o mal, por principiar. Esses homens! Todos puxavam o mundo para si, para o concertar consertado. Mas cada um só vê e entende as coisas dum seu modo." (João Guimarães Rosa - Grande Sertão Veredas)

\section{CONSIDERAÇÕES INICIAIS}

A judicialização dos direitos sociais e econômicos, cuja satisfação exige do Estado prestações de cunho material e, em decorrência, o dispêndio de recursos públicos, é um tema bastante sensível do ponto de vista da democracia. Quando essas prestações passam a ser definidas e deferidas por magistrados, costuma-se argumentar que a distribuição dos recursos públicos e bens sociais manifesta o caráter de coletividade de uma sociedade e, por isso, são atitudes que concernem ao povo e seus representantes diretamente eleitos, e não à elite da magistratura. Identifica-se, neste argumento, um ponto de convergência entre a direita, a esquerda e o centro: "a imposição judicial de direitos sociais e econômicos é ilegítima porque contradiz nosso compromisso com as formas democráticas de governo".

Porém, o déficit democrático não é o único problema em torno da atuação judicial na área dos direitos sociais, e a questão costuma ser analisada pelos prismas da subversão do princípio da separação de poderes e da escassez de recursos ${ }^{1}$. Outros

1 Conferir, a esse respeito, alguns trabalhos referenciais de RAMOS, Elival da Silva. O direito à saúde em face da discricionariedade administrativa. In: MARQUES NETO, Floriano de Azevedo (coord.). Direito e administração pública: estudos em home- 
enfoques encontram-se em pleno desenvolvimento, como o estudo das capacidades institucionais para lidar com certas questões e a teoria do diálogo institucional2. O foco do presente estudo concentra-se neste último aspecto, cumprindo examinar o quadro existente em face do desenho institucional que seria mais adequado para lidar com o direito à saúde em juízo.

Estudos observam que, em face da judicialização dos direitos sociais, dos quais a saúde é espécie, três orientações são encontradas na jurisprudência do STF. Na primeira, existe uma política pública e o direito está regulamentado, e o Judiciário, ao deferir determinada prestação, está apenas a determinar seu cumprimento, numa manifestação típica da função jurisdicional stricto sensu, sem que se verifique qualquer exacerbação no exercício das competências constitucionalmente cometidas ao Judiciário. Na segunda, a política pública já foi implementada e está sendo executada, mas o Judiciário concede prestação que não foi previamente incluída pelo Poder Público (omissão parcial). Neste caso manifesta-se um ativismo judicial na imposição de deveres à Administração Pública sem prévia cominação legal ou provisão orçamentária, tanto em demandas coletivas quanto em individuais. Esta hipótese revela-se particularmente delicada à medida que a concessão de medicamentos e terapias não registrados pressupõe conhecimentos técnicos que os magistrados geralmente não possuem. $\mathrm{Na}$ terceira situação, inexiste a política pública de cunho social (omissão total) e o Judiciário determina que seja implementada. O deferimento de uma prestação fática individual nesses casos, a despeito da inexistência de qualquer regulamentação normativa, caracteriza uma forma de ativismo judicial e os mesmos problemas de falta de conhecimento técnico relativo à saúde. Contudo, no caso das demandas coletivas (geralmente por ação civil púbica), em vez de conceder prestações materiais, o Poder Judiciário tem determinado que os poderes competentes tomem providências no sentido de formular e implementar a política pública para atender prioridade já fixada na Constituição Federal. ${ }^{3}$

Esta última alternativa é uma nova tendência na Corte, parecendo preferível porque, nessa hipótese, as competências legislativas e administrativas restariam preservadas, havendo apenas uma determinação para que executem suas funções e cumpram os deveres constitucionalmente impostos; tampouco haveria violação ao princípio de

nagem a Maria Sylvia Zanella Di Pietro. São Paulo: Atlas, 2013. p. 482-510. MELLO, Claudio Ari. Democracia constitucional e direitos fundamentais. Porto Alegre: Livraria do Advogado Editora, 2004. BARCELLOS, Ana Paula de. Constitucionalização das políticas públicas em matéria de direitos fundamentais: o controle político-social e o controle jurídico no espaço democrático. In: SARLET, Ingo (org.). Direitos fundamentais, orçamento e "reserva do possível". Porto Alegre: Livraria do Advogado Editora, 2008. p. 111-147; AMARAL, Gustavo. Direito, escassez e escolha: em busca de critérios jurídicos para lidar com a escassez de recursos e as decisões trágicas. Rio de Janeiro: Renovar, 2001.

2 Neste tema o estudo de referência é de BRANDÃO, Rodrigo. Supremacia judicial versus diálogos constitucionais: a quem cabe a última palavra sobre o sentido da constituição? Rio de Janeiro: Lumen Juris, 2012.

3 Cf. AVILA, Ana Paula O.; MIRANDA, Paula Mandagará. Supremo Tribunal Federal: ativismo ou self-restraint na efetivação de direitos sociais? Quaestio luris, Rio de Janeiro, v. 10, p. 519-543, 2017. 
justiça distributiva que guia a formulação de políticas públicas, pelo caráter geral com que será implementada, e nem da segurança jurídica que requer a previsibilidade e calculabilidade quanto aos deveres exigíveis tanto do Estado como do cidadão.

Essa espécie de terceira via de atuação judicial na judicialização das políticas públicas, com o Judiciário colocando-se como um articulador entre os demais poderes, tem sido referido na doutrina constitucional como a teoria do "Diálogo Institucional". Daí o objetivo geral deste trabalho, de analisar a justificativa e a concretização da cooperação interinstitucional exclusivamente na área da saúde. Com efeito, a tradicional polarização autocontenção $x$ ativismo judicial está cedendo espaço a uma nova forma de relação, voltada a potencializar as capacidades institucionais de cada órgão, evitando que o Judiciário se sobreponha ou se substitua aos demais órgãos responsáveis.

O recorte do objeto para circunscrevê-lo à questão da saúde justifica-se à medida que, nesta área, essa transformação de paradigma é vital (literalmente), pois o respeito à capacidade institucional dos órgãos técnicos atende a uma necessidade decorrente da enorme complexidade das questões referentes à saúde humana. Tais questões reclamam o emprego de conhecimentos e padrões técnico-científicos da medicina que escapam, por razões óbvias, do ofício dos juízes, que são agentes com outro tipo de formação, capacitados para lidar com as questões jurídicas. $O$ tema assume ainda maior relevo no momento em que se realiza, no Supremo Tribunal Federal, o julgamento da repercussão geral de ações que versam sobre o dever de fornecimento, pelo Estado, de medicamentos de alto custo.

Para o objetivo enunciado, de justificar e demonstrar como se concretiza o diálogo institucional a partir das questões de saúde judicializadas, empregou-se o método de revisão bibliográfica, documental e jurisprudencial, além da descrição da atuação de diferentes órgãos envolvidos em conjunto com o Judiciário em situações locais, o que só foi possível a partir da observação empírica (em todo caso documentada em fontes de acesso ao público).

A pesquisa foi organizada em duas partes para, primeiro, em análise interdisciplinar, detalhar as especificidades, a complexidade e os interesses presentes nas questões referentes à saúde e à discricionariedade técnica, com o objetivo de demonstrar que falta ao Poder Judiciário capacidade para, sozinho, lidar com essas questões. Em seguida, será analisada a participação do Judiciário na questão, em contraste com a questão das capacidades institucionais, e como a teoria do diálogo institucional pode contribuir para promover a interação entre os órgãos técnicos e o Poder Judiciário. A fim de demonstrar concretizações desse fenômeno e um desenho institucional adequado às suas vicissitudes, serão analisadas algumas experiências específicas que já estão em vigor em alguns municípios do país e os parâmetros que servem de referência aos casos em que a tutela de prestações à saúde couber ao Poder Judiciário. 
As observações finais evidenciarão que a complexidade da área da saúde sugere a necessidade de outros arranjos que evitem que a matéria permaneça confinada no âmbito das cortes judiciais, integrando as capacidades de diversas instituições que, isoladamente, sempre apresentarão suas imperfeições e vicissitudes. É sempre uma escolha entre alternativas imperfeitas, ${ }^{4}$ mas veremos que a situação da saúde demonstra com solar clareza que os raciocínios estritamente jurídicos e o mundo do Direito possuem suas limitações e somente uma aproximação interinstitucional é capaz de responder satisfatoriamente às dificuldades nesta área.

\section{A COMPLEXIDADE DA SAÚDE HUMANA: MÉDICOS, INDÚS- TRIAS FARMACÊUTICAS, ADVOGADOS E ONGS}

Entre os fatores que chamam atenção em relação à saúde, os números sobressaem - tanto os referentes aos valores despendidos quanto o número de ações que tramitam na justiça. 5 Tais números, de um lado revelam o grau de inefetividade do direito à saúde e, de outro, podem traduzir uma concepção equivocada acerca da capacidade do Poder Judiciário para aquilatar todos os interesses envolvidos na questão, em particular na prescrição de tratamentos e medicamentos a pacientes.

Situação ilustrativa da judicialização da saúde, alvo de milhares de liminares no país nos últimos meses, foram diversas condenações do Poder Público ao fornecimento da substância fosfoetanolamina6, utilizada em pesquisas preliminares no tratamento do câncer, doença que apresenta diversas manifestações e tratamentos. Nesta era da velocidade e informação, disseminou-se a promessa de que a droga representava a descoberta da cura do câncer. Como decorrência, sem o aval de quaisquer autoridades da oncologia ou do INCA (Instituto Nacional do Câncer) que atestassem níveis mínimos de segurança na utilização desta substância, o Poder Judiciário vinha concedendo as liminares que exigiam o fornecimento da fosfoetanolamina até que o STF suspendesse a eficácia da lei7.

A perplexidade da comunidade médica diante do deferimento judicial liminar da fosfoetanolamina, apesar da falta de validação científica, não é desmesurada

\footnotetext{
4 KOMESAR, Neil. F. Taking Institutions Seriously: introduction to a strategy for constitutional analysis. The University of Chicago Law Review, Chicago, vol. 51, n. 2, p. 366-446, mar./may 1984. p. 24.

5 Só no Tribunal de Justiça do Rio Grande do Sul, tramitam 113.953 demandas na área da saúde. Em termos comparativos, em um segundo lugar distante está o TJSP com 44.690 ações e em terceiro o TJRJ, com 25.234 ações em tramitação. Dados disponíveis em: <http://www.cnj.jus.br/noticias/cnj/57537-sp-rs-e-rj-sao-estados-que-mais-concentram-processos-na-areade-saude>. Acesso em 3 de setembro de 2016.

${ }^{6}$ A então Presidente Dilma Rousseff sancionou a Lei n. 13.269 em 13 de abril de 2016, aprovada sem alterações de texto pelo Congresso Nacional, autorizando o uso da substância fosfoetanolamina sintética para doentes com neoplasias malignas. Disponível em: <http://www.planalto.gov.br/ccivil_03/_Ato2015-2018/2016/Lei/L13269.htm>. Acesso em 28 de out. de 2016.

7 Por maioria de votos, o Plenário do STF deferiu medida liminar na ADI 5501 para suspender a eficácia da Lei 13.269/2016 e, por consequência, o uso da fosfoetanolamina. Disponível em: <http://www.stf.jus.br/portal/cms/verNoticiaDetalhe.asp?idConteudo=31701 >. Acesso em: 28 de out. de 2016.
} 
quando se pensa que no centro da questão pode estar justamente o declínio à saúde do indivíduo. Para dar uma ideia da gravidade e do risco implicado em tais decisões, recorde-se um dos mais terríveis acidentes médicos da história, originado na Alemanha ao final da década de 1950, quando dois pesquisadores do laboratório farmacêutico Grünenthal, após testes em roedores, desenvolveram e lançaram no mercado medicação antiemética, sedativa e hipnótica que foi considerada muito segura e de poucos efeitos colaterais, para ser comercializada com indicação principalmente para os enjoos matinais e ansiedade das grávidas. O medicamento foi anunciado como "inteiramente atóxico", "completamente inócuo", "completamente seguro" e vendido sem receita médica8. Assim, em 1957 entrou no mercado alemão, e logo após em mais de 146 países, a droga Talidomida, e em 1961, foi descoberta sua associação a malformações congênitas (a Focomelia), ocasião em que a medicação teve o uso suspenso ${ }^{9}$. Tarde demais: em 1962 já haviam sido descritos mais de 10.000 casos de Focomelia ao redor do mundo, os chamados "filhos da Talidomida".10

Esses episódios envolvendo a fosfoetanolamina e a talidomida trazem à tona vários aspectos necessários para a compreensão da enorme complexidade da área da saúde, que vão muito além do paciente (titular do direito à saúde) por envolver diversos agentes e interesses nessa área: a classe médica como detentora do conhecimento da ciência e dos protocolos clínicos validados para avaliação de doenças e prescrição de tratamentos; os interesses no mercado da saúde, considerando especialmente os laboratórios farmacêuticos que atuam no mercado da saúde, além de ONGs e escritórios de advocacia interessados na judicialização.

Os médicos são os profissionais responsáveis pelos cuidados da saúde dos seus pacientes, competindo-lhes a tarefa de detecção e diagnóstico de doenças, com a indicação dos tratamentos adequados e indispensáveis à cura ou melhora na condição do paciente. A grande complexidade e as graves consequências envolvendo a tomada de decisões na área da saúde tem levado, cada vez mais, à produção de protocolos em todos os níveis de complexidade com a chamada "medicina baseada em evidências científicas". Trata-se de uma prática que se originou em universidades do Canadá na

\footnotetext{
8 Dados colhidos em: BRASIL. Ministério da Saúde. Secretaria de Vigilância em Saúde. Departamento de Vigilância das Doenças Transmissíveis. Talidomida: orientação para o uso controlado. Brasília: Ministério da Saúde, 2014. Disponível em:<http://bvsms. saude.gov.br/bvs/publicacoes/talidomida_orientacao_para_uso_controlado.pdf $>$. Acesso em 3 de ago. 2016. p.14.

9 Dados da A.B.P.S.T. - Associação Brasileira dos Portadores da Síndrome Talidomida. Disponível em: < http://www.talidomida. org.br>. Acesso em 3 ago. de 2016.

10 Os Estados Unidos da América tiveram os efeitos da tragédia mitigados devido à firme atuação e controle da Food and Drug Administration (FDA) que não considerou adequados os testes clínicos apresentados pela indústria farmacêutica à época. Ainda assim, cerca de 1.200 médicos americanos receberam a Talidomida diretamente da empresa Grünenthal e prescreveram-na para suas pacientes gestantes com enjoos. No Brasil, a droga Talidomida foi proibida para utilização por mulheres em idade fértil, ou seja, da menarca à menopausa (portaria $\mathrm{n}^{\circ} 354$, mar./1997) mas ainda é comercializada com recomendação de rígido controle, tem mais de 60 indicações de tratamento, sendo utilizada para câncer de medula, hanseníase, lúpus e alívio de sintomas de portadores do HIV, o Brasil é o maior fabricante de Talidomida no mundo, com o aval do governo (Lei 10.651, abr./ 2003 dispõe sobre o controle do uso da Talidomida). Lei 12.190/2010 que complementa Lei 7.070/1982 dispõe sobre pensão especial para os portadores de deficiência decorrente do uso da Talidomida no Brasil.
} 
década de 80 , com o objetivo de reduzir incertezas na tomada de decisões relativas à saúde conforme as melhores evidências produzidas em experimentos científicos bem delineados, com auxílio da epidemiologia clínica, metodologia científica, estatística e informática. ${ }^{11}$

Os estudos que dão suporte a esses protocolos são classificados e graduados por sistema alfabético e/ou numérico, determinando basicamente se o nível de evidência que consubstancia o uso de uma terapêutica, ou mesmo a utilização de uma nova tecnologia como método diagnóstico, é alto, médio ou baixo.12 Muitas variáveis são consideradas, inclusive a existência de eventual conflito de interesses, como por exemplo, o pesquisador que anuncia uma significativa descoberta médica tendo recebido o patrocínio de indústria farmacêutica.

A judicialização da saúde implica, é certo, a atuação do médico, que prescreve determinado tratamento ou medicamento que vem a ser pleiteado pela via judicial. Em que pese a relevância da opção pelo tratamento indicado, a questão vai muito além da decisão do médico porque implica o custo referente aos tratamentos e medicamentos prescritos, que devem ser financiados por alguém (no caso, pelo Estado) e proporcionam elevados lucros neste mercado. Como em todo mercado lucrativo, diversos interesses atuantes e por vezes conflitantes podem ser identificados. A par do interesse do próprio paciente, uma pequena amostragem de casos ocorridos no Brasil evidencia que há outros interesses presentes. A propósito do julgamento sobre os medicamentos de alto custo pelo STF, a Revista Época divulgou matéria sobre "o caso do paciente de R\$ 800 mil", referindo-se a um paciente portador de uma rara anemia, a Hemoglobinúria Paroxística Noturna (HPN), que promove uma série de complicações como a trombose em diversos órgãos e pode levar à morte.13

O tratamento para a HPN é feito com o medicamento Eculizumab (nome comercial Soliris ${ }^{\circledR}$ ), ao custo de R\$ 800 mil por ano, pago pelo Sistema Único de Saúde em obediência à decisão judicial que impôs ao governo estadual o fornecimento do tratamento. ${ }^{14} \mathrm{O}$ hematologista responsável pela prescrição do medicamento, foi também quem indicou a advogada para a demanda judicial contra a Secretaria Estadual de Saúde. O médico nega vínculos com o fabricante do remédio (Laboratório Alexion),

\footnotetext{
11 SARTORI JUNIOR, Dailor et al. Judicialização do acesso ao tratamento de doenças genéticas raras: a doença de Fabry no Rio Grande do Sul. Ciênc. Saúde Coletiva, Rio de Janeiro, v. 17, n. 10, p. 2717-2728, Out. 2012. Disponível em: <http://www.scielo.br/scielo.php?script=sci_arttext\&pid=S1413-81232012001000020\&lng=en\&nrm=iso>. Acesso em: 27 Out. 2016. p. 2717.

12 FUCHS, Flávio Danni; WANNMACHER, Lenita; FERREIRA, Maria Beatriz Cardoso. Farmacologia Clínica: fundamentos da terapêutica racional. 3. ed. Rio de Janeiro: Guanabara Koogan, 2006. p. 72; 75.

13 Dados da Revista Época: "o Soliris ${ }^{\oplus}$ melhora a qualidade de vida e necessita ser utilizado pelo resto da vida, não elimina totalmente o risco de trombose e há necessidade de uso de anticoagulante concomitantemente; porém, tal enfermidade poderia ser curada com o transplante de medula, alternativa mais barata com custo de $\mathrm{R} \$ 50 \mathrm{mil}$ (o transplante cura metade das pessoas com HPN, há risco de morte ou complicações graves em cerca dos $30 \%$ dos casos). Nunca foi procurado um doador para o paciente, uma vez que o tratamento foi alcançado pela via judicial". Disponível em: <http://revistaepoca.globo.com/tempo/ noticia/2012/03/o-paciente-de-r-800-mil.html>. Acesso em: 4 de setembro de 2016.
}

14 Processo 053.10.034026-4 - Mandado de Segurança para Fornecimento de Medicamentos, tramitando em São Paulo. 
mas dele recebe pagamentos para dar aulas a outros médicos sobre o HPN. A advogada indicada pelo hematologista recebe honorários da Associação Brasileira de HPN, uma ONG que recebe apoio financeiro da Alexion. O governo estadual paulista foi obrigado ao pagamento desse tratamento para outros 34 pacientes no ano de 2011, tendo a mesma advogada atuado em 28 desses casos. 15

Devidamente contextualizada a judicialização neste caso, de pronto se percebe a importância do interesse econômico farmacêutico nas ações em saúde. Em contraponto, nos últimos anos verificou-se o aumento do número de sífilis congênita em decorrência do desabastecimento da medicação Penicilina Benzatina em todos os estados brasileiros, sendo que um dos principais motivos para a dificuldade no fornecimento e disponibilização na rede pública deve-se ao fato de ser considerada uma droga muito barata, proporcionando baixo lucro aos fabricantes ${ }^{16}$.

O quadro sugere que no âmbito da judicialização existe um perfil possivelmente elitizado de quem alcança o sistema judiciário, conclusão já demonstrada em relevantes pesquisas acadêmicas e científicas ${ }^{17}$. Estudos revelam que alguns tipos de tratamentos experimentais e medicamentos recém lançados pela indústria estão associados a grupos repetidos de médicos e advogados particulares que patrocinam tais demandas no Judiciário18.

De vários estudos compilados, Fábio Quintas conclui que a preponderância de médicos e advogados do setor privado contrapõe a crença de que as demandas judiciais

\footnotetext{
15 Na mesma reportagem da Época disse o secretário da saúde do Estado de São Paulo, Giovanni Guido Cerri: "isto virou uma grande indústria. Alguns médicos recebem estímulos do fabricante (viagens, benefícios) para prescrever medicamentos de alto custo. As empresas financiam as ONGs de pacientes e a isso tudo se associam os advogados." Completa dizendo: "a judicialização da saúde é uma injustiça, os mais ricos desviam recursos dos mais pobres".

16 Centers for Disease Control and Prevention. "Sexually transmitted diseases treatment guidelines, 2015. MMWR, 64 (RR-03): 43-45." (2015). Disponível em:< http://www.cdc.gov/std/tg2015/syphilis-pregnancy.htm>. Acesso em 1 de setembro de 2016. Ainda: Medscape notícias e perspectivas: Desabastecimento de penicilina alerta para desafio global de combate à síflis. Disponível em: <http://portugues.medscape.com/verartigo/6500488>. Acesso em 4 de setembro de 2016.

17 Conferir, a propósito: MEDEIROS, Marcelo; DINIZ, Debora; SCHWARTZ, Ida Vanessa Doederlein. A tese da judicialização da saúde pelas elites: os medicamentos para mucopolissacaridose. Ciênc. saúde coletiva, Rio de Janeiro, v. 18, n. 4, p. 1079-1088, Apr 2013. Disponível em <http://www.scielo.br/scielo.php?script=sci_arttext\&pid=\$1413-81232013000400022\&lng=en\&nrm=iso>. Acesso em 21 Abril de 2016; PEREIRA, Jane Reis Gonçalves. Direitos sociais, Estado de Direito e desigualdade: reflexões sobre as críticas à judicialização dos direitos prestacionais. Quaestio Juris, Rio de Janeiro, vol. 8, n. 3, 2015. DOI: http://dx.doi. org/1012957/rqi.2015.

18 Um desses estudos, da autoria de Fábio Quintas, fez a compilação de vários estudos sobre as ações judiciais pleiteando medicamentos, concluindo que essas demandas podem estar servindo aos interesses da indústria farmacêutica. Em uma das análises do Estado de Minas Gerais, publicada em 2012, que reuniu ações entre 1999 e 2009 (foram 2.412 ações solicitando 2.880 medicamentos), verificou-se que $62,1 \%$ tinha representação de advogados particulares e $84,9 \%$ das prescrições foram feitas por médicos do setor privado; um único escritório de advocacia foi responsável por $44,8 \%$ das demandas e, dentre estas, um único médico prescreveu tratamento em $43,6 \%$ dos casos do medicamento adalimumabe, anticorpo monoclonal usado para tratar artrite reumatóide que não é primeira escolha nos protocolos do SUS (QUINTAS, Fábio Lima. Juízes-administradores, a intervenção judicial na efetivação dos direitos sociais. Revista de Informação Legislativa, Brasília, ano 53, n. 209, mar. 2016. p. 37-38). Estudo sobre ações judiciais no Estado de São Paulo, em 2006, observou dados similares: em 2.967 ações, $97,2 \%$ foram ajuizadas por advogados privados, implicando gastos de $\mathrm{R} \$ 65$ milhões no atendimento de tratamentos médicos para 3.600 pessoas. Outro estudo no mesmo Estado, em 2006-2007, com dados da Secretaria de Saúde estadual, verificou dispêndio de cerca de R\$ 40 milhões para atender 1.220 pedidos de tratamento, com custo médio de $\mathrm{R} \$ 33,5$ mil por paciente (QUINTAS, Fábio Lima. Juízes-administradores, a intervenção judicial na efetivação dos direitos sociais. Revista de Informação Legislativa Brasília, ano 53, n. 209, mar. 2016. p. 38-39).
} 
nesta área promovem auxílio aos pobres e marginalizados por políticas públicas insuficientes. Sugere, ainda, que alguns grupos desses profissionais atendem aos interesses da indústria farmacêutica, compelindo o poder público a financiar medicamentos de alto custo em detrimento de opções menos onerosas e que atenderiam às patologias dos demandantes sem provocar desequilíbrios no orçamento ou nas políticas universais. Para Quintas, o ativismo judicial na saúde interfere na ordenação do direito e debilita a atividade administrativa, solapando a competência do administrador: torna-se o juiz "a grande agência administrativa do Brasil - a última instância administrativa".19 Na mesma linha é a advertência de Marina Machado, de que

essas ações podem representar interesses daqueles que comercializam medicamentos novos e financeiramente inacessíveis à população em geral. O SUS, que possui a atribuição de garantir a todos o direito à saúde, tornou-se um grande mercado consumidor para os novos lançamentos da indústria farmacêutica, que nem sempre atendem às necessidades sanitárias da população. ${ }^{20}$

A licenciosidade no relacionamento entre médicos e indústria farmacêutica também se identifica em estratégias de mercado e investimentos neste setor, implicando no afrouxamento dos critérios de observância bioética em detrimento dos indivíduos e das políticas públicas. Dentre as variadas técnicas de aliciação estão a distribuição de brindes diversos nos consultórios médicos, o oferecimento de ingressos para eventos desportivos, o pagamento de jantares refinados e de viagens para locais paradisíacos, até o franco patrocínio para os profissionais que prescrevem determinados tratamentos. 21

Márcia Angell escreveu um livro intitulado "A verdade sobre os laboratórios farmacêuticos" descrevendo diversas práticas por eles encetadas no mercado da saúde. Por exemplo, os investimentos em publicidade no mercado farmacêutico envolvem cifras astronômicas e revelam a capacidade da indústria para influenciar e criar demanda para o uso de seus produtos. ${ }^{22} \mathrm{~A}$ autora também alerta para a enxurrada de lançamen-

19 QUINTAS, Fábio Lima. Juízes-administradores, a intervenção judicial na efetivação dos direitos sociais. Revista de Informação Legislativa, Brasília, ano 53, n. 209, mar. 2016. p. 38-40.

20 MACHADO, Marina Amaral de Ávila et al. Judicialização do acesso a medicamentos no Estado de Minas Gerais, Brasil. Rev. Saúde Pública, São Paulo, v. 45, n. 3, p. 590-598, jun. 2011. Disponível em <http://www.scielo.br/scielo.php?script=sci_arttext\&pid=S0034-89102011000300018\&lng=en\&nrm=iso >. Acesso em 21 Abril de 2016. p. 594.

21 OLIVEIRA, Luciano Moreira de. Análise da relação entre laboratórios farmacêuticos e médicos do Sistema Único de Saúde à luz do princípio da moralidade administrativa. Revista de Informação Legislativa, Brasília, vol. 52, n. 205, jan./mar. 2015. Disponível em: <http://www2.senado.gov.br/bdsf/item/id/509950>. Acesso em: 20 de ago.de 2016. p. 214.

22 Dados norte-americanos dão conta de que no ano de 2001 foram distribuídos cerca de US\$ 11 bilhões em "amostras grátis" dentre os medicamentos mais caros e recém lançados no mercado pelos representantes dos laboratórios farmacêuticos nos consultórios médicos, custo evidentemente incluído no valor final de venda do remédio, promovendo a familiarização do prescritor da droga e do paciente no seu uso (ANGELL, Márcia. A verdade sobre os laboratórios farmacêuticos. 2. ed. Rio de 
tos de medicamentos que apontam benefícios tão diversificados quanto amplos e difíceis de aferir, para combater moléstias de definição vaga ou indisposições corriqueiras que, na história natural da doença, melhorariam espontaneamente muito mais rapidamente do que com o excesso de medicação e seus efeitos colaterais e interações medicamentosas. 23

Além disso, medicamentos novos, mesmo após passarem por rigorosos estudos até o seu registro pela agência sanitária, carregam a potencialidade de, com a ampliação do uso e tempo no mercado, acabarem demonstrando graves efeitos adversos, inclusive fatais; logo, não se pode conhecer a segurança de um medicamento que esteja sendo comercializado há pouco tempo. ${ }^{24}$

Essas afirmações são sustentadas por estatísticas e dados empíricos: as ONGs Public Citizen e a Acción Internacional para la Salud divulgaram dados sobre a retirada de medicamentos do mercado após eventos graves e fatais. Oito (8) dentre onze (11) medicamentos retirados do consumo entre os anos de 1992 e 2001, foram retirados com menos de dois anos de comercialização, um apenas ultrapassou cinco anos no mercado até ser retirado e cinco deles não permaneceram em venda por nem mesmo um ano. Esses registros denotam a importância da "farmacovigilância" das agências sanitárias, especialmente quanto aos novos medicamentos. Diversos estudos em todo o mundo apontam que, na melhor das hipóteses, apenas um terço de todos os remédios novos levados a registro apresentam alguma vantagem terapêutica quando comparados aos já existentes para as mesmas indicações e, em média, o baixo percentual de $3 \%$ representaria avanço terapêutico substancial. 25

Não bastasse tudo isso, o setor também se apresenta propício ao cometimento de fraudes 26 e, neste quesito, o Brasil tem suas histórias envolvendo médicos e indústria. Recente investigação expôs grande esquema criminoso conhecido como "Máfia das Próteses", demonstrando o conluio entre médicos traumato-ortopedistas e fornecedores de material protético de alto custo, em que recebiam valores superfaturados em cirurgias e procedimentos utilizando material de custo elevado e de qualidade e

Janeiro: Record, 2007. p. 131). Do ponto de vista estratégico, as amostras grátis são consideradas os presentes mais eficazes para popularizar medicamentos novos, que, depois de algum período de uso, podem acabar demonstrando maiores efeitos adversos do que as medicações antigas consagradas e de menor custo, deixadas de lado pela indução publicitária subliminar de que o novo medicamento necessariamente superaria o antigo (ANGELL, Márcia. A verdade sobre os laboratórios farmacêuticos. 2. ed. Rio de Janeiro: Record, 2007. p. 144-145).

23 ANGELL, Márcia. A verdade sobre os laboratórios farmacêuticos. 2. ed. Rio de Janeiro: Record, 2007. p. 141.

24 COSTA, Ediná Alves. Vigilância Sanitária, desafios à construção de um sistema nacional para a proteção da saúde. In: NOBRE, Milton Augusto de Brito; SILVA, Ricardo Augusto Dias da (Coords.). O CNJ e os desafios da efetivação do direito à saúde. 2 ed. Belo Horizonte: Fórum, 2013. p. 52-53; FUCHS, Flávio Danni. Terapêutica na Prática Clínica cardiovascular: Vivências e Evidência. Arq. Bras. Cardiol. , São Paulo, v. 85, n. 1, p. 72-75, Julho de 2005. Disponível em: <http://www.scielo.br/scielo.php?script=sci_arttext\&pid=S0066-782X2005001400015\&lng=en\&nrm=iso >. Acesso em 27 de outubro de 2016. p. 75.

25 COSTA, Ediná Alves. Vigilância Sanitária, desafios à construção de um sistema nacional para a proteção da saúde. In: NOBRE, Milton Augusto de Brito; SILVA, Ricardo Augusto Dias da (Coords.). O CNJ e os desafios da efetivação do direito à saúde. 2 ed. Belo Horizonte: Fórum, 2013. p. 53-54.

26 ANGELL, Márcia. A verdade sobre os laboratórios farmacêuticos. 2. ed. Rio de Janeiro: Record, 2007. p. $146-147$. 
indicação duvidosas27. O episódio expressa o prejuízo para o Estado causado por decisões judiciais que chancelam este tipo de recomendação médica, solicitando determinado tratamento de alto custo motivado por suborno e submetendo o paciente aos riscos de um procedimento cirúrgico desnecessário ou de eficácia duvidosa28.

Passar a lupa sobre todos esses interesses torna muito singelas as abordagens que reduzem a judicialização ao problema da efetividade do direito à saúde das pessoas necessitadas. Em se tratando de área tão economicamente relevante, como a da indústria farmacêutica, a meritória previsão constitucional do direito à saúde integral para todos pode ser utilizada de forma maliciosa por quem detém poder e interesses econômicos, e se vale da exposição do sofrimento humano e da chancela judicial para aumentar os lucros decorrentes da atividade.

Esse exame mais alentado dos interesses presentes na questão importa à medida que o STF, órgão de cúpula do Poder Judiciário, como dito na introdução deste estudo, tem decisões em que considera sua atuação na área da saúde adequada, legítima e necessária, reconhecendo o dever de alcançar judicialmente prestações fáticas ao postulante, inclusive quando os tratamentos e medicamentos postulados não estão contemplados nos programas que o Sistema Único de Saúde disponibiliza aos seus usuários e nem aprovados para registro na ANVISA. Cumpre, por isso, passar à análise mais detida da atuação institucional do Judiciário na complexidade da saúde para compreender como chegou-se a esse quadro e quais as propostas para aprimorar sua participação na solução do problema.

\section{A ATUAÇÃO DO PODER JUDICIÁRIO NO COMPLEXO QUADRO DA SAÚDE}

Por judicialização29 entende-se o grande protagonismo do Poder Judiciário na implementação das políticas públicas, por meio das mais variadas decisões judiciais

\footnotetext{
27 Reportagem no programa televisivo Fantástico em janeiro de 2015. Disponível em: http://g1.globo.com/fantastico/noticia/2015/01/mafia-das-proteses-coloca-vidas-em-risco-com-cirurgias-desnecessarias.html. Acesso em 20 de ago. de 2016.

28 A iniciativa privada é igualmente lesada quando, em busca da eficácia horizontal dos direitos fundamentais, o consumidor judicializa determinadas pretensões em face do plano de saúde que tenha glosado recomendações médicas de uso de determinados materiais de alto custo ou sem comprovação científica da sua eficácia clínica. Neste sentido, Duque demonstra a eficácia dos direitos fundamentais nas relações de direito privado (Drittwirkung) calcada nas relações de consumo, pois há irradiação dos direitos fundamentais em todo o âmbito jurídico na chamada teoria do diálogo das fontes convergindo na interpretação do direito civil para a Constituição (DUQUE, Marcelo Schenk. Direito privado e constituição: Drittwirkung dos direitos fundamentais, construção de um modelo de convergência à luz dos contratos de consumo. São Paulo: Revista dos Tribunais, 2013. p. 413).

29 Lênio Streck esclarece as diferenças entre judicialização e ativismo: enquanto a judicialização está ligada a problemas contingenciais, o ativismo liga-se a problemas comportamentais. $\mathrm{O}$ autor considera que a judicialização ocorre na maioria das democracias e não é um mal em si, decorre, em regra, das (in)competências na execução das políticas públicas; o ativismo, por outro lado, manifesta-se quando o juiz subjetivamente imiscui-se nos juízos políticos e morais do legislador, sua vontade e juízos pessoais substituem o debate político. Para Streck, o ativismo judicial pode ocorrer no uso de técnicas como a "interpretação conforme", realizada pelo STF, cuja conformidade da interpretação muitas vezes dá-se no sentido oposto à proposição do legislador, bem como pelo uso das prerrogativas de livre convencimento e livre apreciação das provas pelo juiz, que podem justificar decisões de qualquer modo, contrariando o princípio democrático em prol de um protagonismo judicial. Streck alerta para os
} 
que garantem o acesso, à título individual ou coletivo, aos bens jurídicos que implicam o dispêndio de verba pública. Essa prática sujeita-se à crítica de que o Judiciário vem se imiscuindo inclusive nas questões de natureza política afetas aos outros poderes, e se associa ao fenômeno denominado "neoconstitucionalismo"30 ou "pós-positivismo".31

Segundo o Min. Luís Roberto Barroso, algumas das principais causas da judicialização encontram-se no processo de redemocratização do país com o novo paradigma constitucional de 1988, pela constitucionalização de uma série de direitos, como os sociais, e o sistema brasileiro de controle de constitucionalidade .32 Antes mesmo de assumir o posto de Ministro do STF, Barroso já disseminava em suas publicações acadêmicas a doutrina centrada na ideia de capacidade institucional, que seria basicamente uma avaliação de qual Poder estaria mais apto a decidir sobre determinadas questões que envolvessem complexidades técnico-científicas, em que as manifestações legislativas e executivas, sufragadas pelo voto, poderiam decidir com mais legitimidade. Neste sentido, ponderava que o

exemplo emblemático nessa matéria tem sido o setor de saúde. Ao lado de intervenções necessárias e meritórias, tem havido uma profusão de decisões extravagantes ou emocionais em matéria de medicamentos e terapias, que põe em risco a própria continuidade das políticas públicas de saúde, desorganizando a atividade administrativa e comprometendo a alocação dos escassos recursos públicos. 33

No Brasil, a judicialização iniciou sua expansão na área da saúde na década de 90. O fenômeno se deve, principalmente, ao crescimento dos índices de infecção pelo vírus HIV, causador da Síndrome da Imunodeficiência Adquirida (SIDA) ou AIDS, no acrônimo em inglês. Em retrospectiva, emblemática é a demanda tendo por objeto medicações para o tratamento da Aids ajuizada pela "menina Lu"34, infectada pelo vírus

riscos, para a representação política, decorrentes do protagonismo ativista judicial, uma vez que ofensas à Constituição pelo Poder Judiciário são mais graves do que as emanadas dos outros Poderes, pois ao Judiciário cabe a guarda do texto constitucional. Fiel ao seu estilo provocativo, questiona: "quem nos salvará dos salvadores?" (STRECK, Lênio Luiz. O que é isto, o ativismo judicial, em números? Os constitucionalistas. Publicação digital, 26 out. 2013. Disponível em: <http://www.osconstitucionalistas.com. br/o-que-e-isto-o-ativismo-judicial-em-numeros>. Acesso em 2 set. 2016.).

30 Para uma clara exposição crítica dos pressupostos do neoconstitucionalismo, conferir: ÁVILA, Humberto. "Neoconstitucionalismo": Entre a "ciência do direito" e o "direito da ciência". Revista Eletrônica de Direito do Estado, n. 17. jan./mar. 2009. p. 1-19.

31 RIBEIRO, Diógenes V. Hassan. Judicialização e Desjudicialização: entre a deficiência do legislativo e a insuficiência do judiciário. Revista de Informação Legislativa, Brasília, v. 50, n. 199, p. 25-33, jul./set. 2013. Disponível em: <http://www2.senado.gov. $\mathrm{br} / \mathrm{bdsf} / \mathrm{item} / \mathrm{id} / 502916>$. Acesso em: 11 de mai. 2016. p. 27.

32 BARROSO, Luís Roberto. $O$ controle de Constitucionalidade no Direito Brasileiro. 4. ed. São Paulo: Saraiva, 2009. p. $322-323$.

33 BARROSO, Luís Roberto. 0 controle de Constitucionalidade no Direito Brasileiro. 4. ed. São Paulo: Saraiva, 2009. p. 343-344.

34 Luciane Aparecida de Conceição, com o uso do coquetel de antirretrovirais, permaneceu com carga viral zero por muitos anos, faleceu aos 24 anos de idade, em 5 de outubro de 2012 de complicações da AIDS por ter se recusado a continuar tomando remédios nos 5 anos que precederam sua morte; engravidou e teve uma filha que nasceu sem o vírus HIV graças a protocolo de uso de antirretrovirais na gestação e no bebê por 6 semanas após o nascimento. Disponível em: <http://g1.globo.com/sao 
HIV ainda no ventre da mãe, devido a uma transfusão de sangue contaminado realizada no Hospital Regional de Sorocaba, no oitavo mês de gestação. A criança nasceu com HIV e aos 8 anos de idade, muito debilitada por doenças oportunistas graves, obteve o coquetel com antirretrovirais via Judiciário em litígio contra a Fazenda Pública. Este caso alcançou grande repercussão por estabelecer no meio médico um precedente de sucesso no tratamento de crianças vivendo com Aids, visto que, até então, as crianças não tinham opções de tratamento35.

A ascensão da epidemia da Aids no Brasil, gerando forte mobilização dos portadores da doença e seus familiares, somada ao processo de redemocratização e à constitucionalização dos direitos sociais no país, estimularam a sociedade civil na busca pelo fornecimento de tratamento para o HIV/Aids, com fulcro no direito à vida e à saúde. Essas ações judiciais foram as precursoras do fenômeno da judicialização da saúde no país. 36

O fato é que esses sucessos obtidos no âmbito judiciário para o tratamento da Aids provocaram uma reestruturação na implementação da política pública de prevenção e tratamento à doença provocada pelo vírus do HIV, tornando-se uma das mais conceituadas no mundo. Em 2001, o boom de ações judiciais atingiu o ápice em decorrência de múltiplos fatores: (a) surgimento de algumas mutações que tornavam o vírus do HIV resistente a certos medicamentos; (b) profícuos investimentos em pesquisa e produção farmacêutica promovendo constante surgimento de novas classes de medicações; (c) demora na incorporação dos novos medicamentos à rede pública; e (d) agressivas campanhas de marketing dos laboratórios produtores dos fármacos. ${ }^{37}$

No ano de 2001 o Programa Estadual de DST/Aids de São Paulo teve seu orçamento público severamente comprometido, com cerca de $80 \%$ despendidos no cumprimento de ordens judiciais, compelindo o programa a fazer suplementação orçamentária. 38 Os embates públicos e judiciais entre o programa nacional de DST/Aids, os

\footnotetext{
-paulo/sorocaba-jundiai/noticia/2012/10/morre-em-sorocaba-sp-primeira-crianca-tomar-coquetel-contra-aids.html>. Acesso em 19 de setembro de 2016 .

35 Também no meio jurídico festejou-se o sucesso alcançado na demanda, o que encorajou o GAPA-SP (Grupo de Apoio à Prevenção da Aids) a distribuir para advogados de ONGs em todo o país os modelos de petições iniciais para serem utilizados em ações semelhantes de solicitação de tratamento para a doença (BRASIL. Ministério da Saúde. Secretaria de Vigilância em Saúde. Programa Nacional de DST e Aids. O Remédio via Justiça: Um estudo sobre o acesso a novos medicamentos e exames em HIV/ aids no Brasil por meio de ações judiciais / Ministério da Saúde, Secretaria de Vigilância em Saúde, Programa Nacional de DST e Aids. Brasília: Ministério da Saúde. 2006. P. 186. Disponível em: <http://bvsms.saude.gov.br/bvs/publicacoes/medic_justica01. pdf $>$. Acesso em 18 de setembro de 2016. p. 25-26).

36 BRASIL. Ministério da Saúde. Secretaria de Vigilância em Saúde. Programa Nacional de DST e Aids. O Remédio via Justiça: Um estudo sobre o acesso a novos medicamentos e exames em HIV/aids no Brasil por meio de ações judiciais / Ministério da Saúde, Secretaria de Vigilância em Saúde, Programa Nacional de DST e Aids. Brasília: Ministério da Saúde. 2006. P. 186. Disponível em: <http://bvsms.saude.gov.br/bvs/publicacoes/medic_justica01.pdf>. Acesso em 18 de setembro de 2016. p. 18.

37 BRASIL. Ministério da Saúde. Secretaria de Vigilância em Saúde. Programa Nacional de DST e Aids. O Remédio via Justiça: Um estudo sobre o acesso a novos medicamentos e exames em HIV/aids no Brasil por meio de ações judiciais / Ministério da Saúde, Secretaria de Vigilância em Saúde, Programa Nacional de DST e Aids. Brasília: Ministério da Saúde. 2006. P. 186. Disponível em: <http://bvsms.saude.gov.br/bvs/publicacoes/medic_justica01.pdf>. Acesso em 18 de setembro de 2016. p. 25-28.

38 Nota oficial do Programa Nacional de DST e Aids, preocupado com a grande quantidade de ações judiciais, em agosto de
} 
defensores dos acometidos pela doença e os pacientes titulares do direito à assistência integral à saúde, escancararam os vícios e as virtudes da judicialização39 neste fenômeno que tem se expandido e preocupado a todos, em face dos riscos de inviabilizar o Sistema Único de Saúde.

No exame da judicialização da saúde, é notório, despontam aspectos positivos, como a mobilização da sociedade civil e das instituições legitimadas para a defesa coletiva e promoção da organização das políticas públicas pelo Poder Público, como se pôde observar com a política Nacional para o tratamento do HIV/Aids. Porém, vê-se o lado negativo em que pacientes, grupos profissionais e indústria dirigem-se diretamente ao Judiciário, em desconsideração às políticas públicas, com propensão a desorganizar o orçamento público, muitas vezes de forma desproporcional, em prejuízo do interesse coletivo.

Há críticas pertinentes que atentam para as injustiças distributivas que as decisões judiciais provocam no orçamento das políticas públicas, tanto pela falta de legitimidade democrática do Judiciário, quanto pela ausência de conhecimento técnico para decisões em tais lides. Alega-se que, ao pretensamente garantir o direito à saúde no caso concreto, o juiz pode estar direcionando orçamento escasso para escolhas de tratamentos que são contrários aos consensos de especialistas médicos, ou mesmo experimentais, e sem nenhuma evidência que consubstancie o deferimento da demanda.

Este último aspecto, concernente às decisões sobre direitos na área da saúde, expõe o problema da capacidade institucional para lidar com as especificidades dos protocolos da medicina baseada em evidências. A dúvida sobre a capacidade dos magistrados é razoável à medida que o processo judicial, que é a missão institucional do Judiciário, serve em geral para definir questões patrimoniais, apurando responsabilidades

2001: “Reconhecemos que o acesso a tratamento é direito indiscutível e decisões dos Tribunais Superiores têm obrigado a disponibilização de medicamentos de todos os tipos (...) deve ser ressaltado que a literatura médico-científica mundial tem, reiteradamente, afirmado que tanto o início como a substituição de drogas antirretrovirais por eventual falha terapêutica não caracterizam uma emergência médica, como grande parte dos advogados que ajuízam esses pedidos vêm colocando em suas petições judiciais. Frequentemente, essa argumentação coloca os juízes em situação difícil, pois como não são conhecedores de assunto tão especializado, veem-se muitas vezes obrigados a expedirem seus mandatos para disponibilização de medicamentos ou exames para cumprimento imediato ( 24 a 48 horas). Assim, a Coordenação Nacional recomenda que se solicite perícia médica judicial, com avaliação individualizada do caso, para permitir a decisão final do juiz, da mesma forma que normalmente ocorre com outros problemas de saúde, particularmente nas áreas cível e trabalhista". (BRASIL. Ministério da Saúde. Secretaria de Vigilância em Saúde. Programa Nacional de DST e Aids. O Remédio via Justiça: Um estudo sobre o acesso a novos medicamentos e exames em HIV/aids no Brasil por meio de ações judiciais / Ministério da Saúde, Secretaria de Vigilância em Saúde, Programa Nacional de DST e Aids. Brasília: Ministério da Saúde. 2006. P. 186. Disponível em: <http://bvsms.saude.gov.br/bvs/ publicacoes/medic_justica01.pdf>. Acesso em 18 de setembro de 2016. p. 28-32)

39 Nota da ONG Grupo de Incentivo à Vida, respondendo à acusação de excessos na solicitação judicial de medicamentos para pacientes que não possuíam indicação: "As decisões da Justiça para garantia de medicamentos fora do consenso terapêutico realmente não podem ser validadas para todos os pacientes. Mas não podemos admitir que as ações sejam genericamente desqualificadas e taxadas de irresponsáveis (...) Foram estas ações judiciais individuais, movidas pelas ONGs em nome dos pacientes, que garantiram ou pelo menos "apressaram" a chegada de diversos medicamentos (...) Jamais abriremos mão de recorrer ao Ministério Público e à Justiça. As ações judiciais são instrumentos de ativismo e de exercício de cidadania; ao lado da garantia de legislações específicas; dos espaços de controle social; da defesa da produção de genéricos e da quebra das patentes; das manifestações públicas e outras formas legítimas de pressão." (BELOQUI, Jorge; SCHEFFER, Mário. Proteção à vida ou transtorno econômico?. Disponível em: <www.giv.org.br>.). 
e determinando eventual reparação por danos causados. No processo, assume centralidade o exame das provas apresentadas para a certificação dos fatos, voltado à aplicação das condutas previamente definidas nas normas jurídicas que regulam aqueles fatos. O processo judicial, nesse sentido, não foi desenhado para lidar com os direitos sociais nas causas em que "o que se questiona é se, ao distribuir as riquezas do Estado, a ação do governo foi justa, e não se o governo causou algum dano ao fazer o que fez". Nesse ponto, Lon Fuller assevera:

os direitos sociais e econômicos manifestam de maneira clássica todas as características das pretensões policêntricas e demonstram a total falta de aptidão do Judiciário para encontrar um meio justo de distribuir os recursos do Estado (...) O fato de haver tantas maneiras diferentes e igualmente legítimas de organizar a assistência médica, a moradia, a educação etc. - no que diz respeito ao tipo de serviço, para quem e por quanto tempo - significa que o processo judicial não é adequado para resolver demandas desta espécie, e o fato de tantos outros poderem fazer reivindicações conflitantes pelos fundos em disputa significa que tampouco os tribunais são adequados. Há tantas causas em que os governos podem gastar dinheiro, bem como tantos indivíduos e grupos, que qualquer decisão tomada por um tribunal será arbitrária e incompleta.

Tais reflexões expõem a fragilidade do Judiciário na matéria e levam a perquirir qual seria, então, a instituição mais adequada para contemplar o problema da saúde. Este é o objeto da seção seguinte, em que serão analisadas as capacidades institucionais dos órgãos responsáveis pelo desenho e implementação das políticas públicas na área da saúde.

\section{O DESENHO INSTITUCIONAL PARA UMA REALIDADE COMPLEXA}

Conquanto a expansão da atividade judicial se justifique sob certos pontos de vista - notadamente quanto à efetivação dos direitos -, não se pode deixar de considerar todas as dificuldades demonstradas na seção anterior, presentes na concretização do direito à saúde e que expõem a fragilidade da capacidade judicial para lidar com esta questão. $O$ debate quanto à capacidade institucional dos órgãos públicos já é antigo e tem entre suas propostas a "análise institucional comparativa", método desenvolvido por Neil Komesar para "decidir quem decide",40 através de um juízo sobre quem, entre os órgãos existentes, detém maior autoridade para o decision making process. ${ }^{41} \mathrm{O}$

\footnotetext{
40 KOMESAR, Neil. F. Taking Institutions Seriously: introduction to a strategy for constitutional analysis. The University of Chicago Law Review, Chicago, vol. 51, n. 2, p. 366-446, mar./may 1984.

41 COSTA, Rafael de Oliveira. Entre o Direito, a Política e a Economia: (re)construindo a análise institucional comparativa. Revista
} 
processo de comparação exige uma interação entre a política, a economia e o direito e tem o mérito de impedir uma análise isolada da atuação judicial, que sempre será comparada a outros cenários possíveis, em que outros atores possam demonstrar maior capacidade para otimizar a implementação das políticas públicas.

Contudo, quando se lida com a questão das capacidades institucionais para argumentar que as Cortes não são as instâncias mais adequadas para ponderar questões de alta complexidade, há que se ter o cuidado, como bem advertem Cléve e Lorenzetto, para que o uso da teoria não se preste a manter o status quo de inefetividade e indefinição em torno dessas questões. Em excelente ensaio, os autores retomam a discussão em torno das capacidades institucionais sob uma perspectiva crítica demonstrando, em primeiro lugar, que ela não é nova e apenas dá continuidade a estudos que remontam aos trabalhos de Henry Hart e Albert Sacks (1994).42 A isso, acrescentaríamos a referência à obra de Neil Komesar, iniciada em 1984 com o ensaio intitulado Taking Institutions Seriously: introduction to a strategy for constitutional analysis, seguida de ensaios de 1987 (Back to the future - an institutional view of making and interpreting Constitutions) e de 1988 ( $A$ job for the judges: the Judiciary and the Constitution in a massive and complex society), e coroada com a monografia Law's Limits: the Rule of Law and the supply and demand of Rights, publicada em 2001 pela Cambridge University Press.

Na perspectiva de Komesar, a questão das capacidades é sempre analisada comparativamente e deve contemplar as potencialidades reais e efetivas, i.e., não idealizadas, de cada instituição, considerando assim suas imperfeições e vicissitudes. Komesar opera na comparação entre o Judiciário e as capacidades do mercado e das instâncias de decisão política como alternativas, advertindo que, antes de deslocar uma questão do âmbito de apreciação judicial em favor de outros sistemas, deve-se em primeiro lugar lembrar que também existem sérias distorções no sistema representativo (onde os interesses de minorias bem articuladas concentradoras de maior renda per capita sobrepõem-se aos interesses da maioria hipossuficiente e dispersa) e também no próprio mercado, onde as condições de competição nem sempre operam em critérios igualitários e leais. Ou seja, nenhuma dessas instituições está livre de fricções (frictionless) quando confrontadas com problemas de grande complexidade, 43 de tal sorte que "todas as instituições são imperfeitas e a escolha entre alternativas pode ser feita sensivelmente pela consideração de seus relativos méritos". Seria a escolha do menor

da Faculdade de Direito - UFPR, Curitiba, vol. 59, n. 2, p. 75-90, 2014. p. 77-78.

42 CLÈVE, Clèmerson Merlin; LORENZETTO, Bruno Meneses. Teorias Interpretativas, Capacidades Institucionais e Crítica. Revista Direitos Fundamentais \& Democracia, Curitiba, v. 19, n. 19, p. 131-168, jan./jun. 2016. p. 159.

43 KOMESAR, Neil. F. Law's Limits: the Rule of Law and the supply and demand of Rights. New York: Cambridge University Press, 2001. p. 22; 28; 61. 
entre os males: “Diante de números expressivos e complexidade, estamos mais para a escolha da melhor entre as alternativas piores ou não atraentes".44

Em segundo lugar, Clève e Lorenzetto salientam, com razão, que nem sempre o desenho institucional diminui o efetivo cometimento de erros, mas apenas transpõe agentes que cometerão erros em outros âmbitos institucionais. Ainda, apontam que resta em aberto "a questão sobre a quem caberia a decisão anterior, a decisão sobre qual seria a instituição mais adequada para decidir o problema, além dos critérios adequados para a avaliação dessa decisão".45 Nesse sentido, a análise institucional comparativa de Komesar ganha sua importância e pavimenta a trilha do diálogo institucional, ao propor uma análise conjunta, jurídica, política e econômica, dos atores, custos procedimentais e competências institucionais, para reconhecer que questões de grande complexidade precisarão de um enfrentamento conjunto (dialógico), e não unilateral (monológico).

Neste ponto, em se tratando do direito à saúde, os aspectos que antes analisamos tornam claro que, se de um lado o Judiciário tem condições de efetivamente contribuir na delimitação da extensão desse direito (veja-se o exemplo da reestruturação administrativa para dar conta do combate à epidemia de HIV), de outro lado, em matérias de natureza técnico-científica, necessitará do auxílio dos órgão técnicos para compreender a natureza e necessidade de terapêuticas específicas para a promoção da saúde (sob o risco de chancelar medicamentos e tratamentos que, ao contrário de promover a saúde do paciente, levam ao seu declínio, com repercussões orçamentárias e prejuízo à coletividade). Não se trata de retirar do Judiciário a capacidade para certas decisões, mas de forçá-lo a reconhecer que a tomada de certas decisões requer a integração de outros atores mais capazes para o processo de decisão.

Deste modo, a complexidade da área reclama conhecimentos técnicos e específicos, que orientam o emprego da discricionariedade técnica dos órgãos decisórios responsáveis pelo desenho e implementação das políticas públicas para o acesso integral, universal e igualitário à saúde, tal como previsto pelo art. 196 da CF/88. Ao isolar o caso concreto de toda a amplitude das questões envolvidas, pode-se, inadvertidamente, proferir uma sentença em que todos perdem: o demandante ao ver provido um tratamento que não era o mais adequado, o poder público que será obrigado a provê-lo e a coletividade que verá diminuído o orçamento da saúde. Com efeito, as diretrizes na área da saúde reúnem uma rede de indicações médicas, critérios demográficos, orçamentos limitados, dados estatísticos etc, que, em regra, encontram dificuldades para

\footnotetext{
44 KOMESAR, Neil. F. Law's Limits: the Rule of Law and the supply and demand of Rights. New York: Cambridge University Press, 2001. p. 24.

45 CLÈVE, Clèmerson Merlin; LORENZETTO, Bruno Meneses. Teorias Interpretativas, Capacidades Institucionais e Crítica. Revista Direitos Fundamentais \& Democracia, Curitiba, v. 19, n. 19, p. 131-168, jan./jun. 2016. p. 158.
} 
serem manejados no contexto binário procedente/improcedente da sentença judicial, ainda que em um devido processo legal.

Por tudo isso, a judicialização das questões da saúde exige uma interação especial entre diversos atores, e novas alternativas são desenhadas para lidar com a especificidade desses problemas. Como exemplo paradigmático, uma magistrada do Poder Judiciário em Araguaína, no Estado do Tocantins, estabeleceu em 2011 um convênio com a Prefeitura, sua Ouvidoria e Secretaria da Saúde, juntamente com um Núcleo de Apoio Técnico (NAT) 46 formado por equipe multidisciplinar de especialistas em saúde pública, enfermeiros, farmacêuticos e médicos. Esta experiência produziu uma redução significativa da judicialização: em 2013 houve resolutividade pela via administrativa de $72 \%$ das demandas em saúde através da Ouvidoria da Prefeitura e da atuação do NAT em parceria com o Ministério Público e a Defensoria Pública, sendo que somente $28 \%$ dos casos seguiram a via judicial; em 2014, apesar de quase o dobro de casos demandando o direito à saúde junto à Ouvidoria, $80 \%$ dos casos foram resolvidos administrativamente. 47 Mais recentemente, em setembro de 2016, foi instaurado mais um NAT na capital do Estado do Tocantins, a cidade de Palmas. ${ }^{48}$

Para Jane Pereira, que observa procedimento semelhante adotado no Rio de Janeiro, esta ferramenta oferece a expertise técnica indispensável para melhorar qualitativa e quantitativamente a atividade judicante, pois

os instrumentos de cooperação são relevantes não apenas por contribuírem para a formação de um processo judicial deliberativo, mas também porque questões envolvendo direitos sociais encerram um amálgama entre saber científico, escolhas políticas e direito. Se não é simples desenhar a linha que traça a fronteira entre direito, técnica e política, fórmulas processuais que viabilizem a interlocução entre os protagonistas de cada um desses domínios contribuem para decisões mais justas, do ponto de vista substantivo, e mais justificadas, do ponto de vista procedimental. 49

\footnotetext{
46 "A função do NAT - Municipal é oferecer suporte de especialistas aos programas de saúde locais sobre as políticas públicas de saúde em vigor, bem como informações técnicas sobre medicamentos e demais procedimentos oferecidos pelo SUS ao Judiciário, ao Ministério Público, à Defensoria Pública. Também tem função de resolver diretamente as questões que estão inseridas na política de saúde do Município, bem como de remeter casos que tenham a possibilidade de resolutividade à Ouvidoria do SUS. Para tanto, foi formada uma equipe multidisciplinar de servidores com especialidades em saúde pública, tais como: assessor jurídico, enfermeiro, farmacêutico, assistente social, assistente técnico administrativo e médico de sobreaviso". Disponível em:<http://www.tjto.jus.br/index.php/listagem-noticias/3291-destaque-nacional-atuacao-do-cemas-e-nat-de-araguaina-e-apresentada-ao-presidente-do-tjto>. Acesso em 17 de setembro de 2016.

47 Documento elaborado pelo TJ-TO. Disponível em:<http://www.tjto.jus.br/index.php/listagem-noticias/3291-destaque-nacional-atuacao-do-cemas-e-nat-de-araguaina-e-apresentada-ao-presidente-do-tjto>. Acesso em 17 de setembro de 2016.

48 Ampliação dos núcleos no Estado de Tocantins. Disponível em: <http://www.cnj.jus.br/noticias/judiciario/83430-tocantins -instala-em-palmas-o-terceiro-nucleo-de-apoio-tecnico-a-saude>. Acesso em 17 de setembro de 2016.

49 PEREIRA, Jane Reis Gonçalves. Direitos sociais, Estado de Direito e desigualdade: reflexões sobre as críticas à judicialização dos direitos prestacionais. Quaestio Juris, Rio de Janeiro, vol. 8, n. 3, 2015. DOI: http://dx.doi.org/1012957/rqi.2015. p. 2112.
} 
Deste modo, a judicialização da saúde passa pelo redimensionamento da importância da discricionariedade técnica nas deliberações que fundamentam o fornecimento ou não de tratamentos na saúde, e também pela valorização do diálogo entre os poderes.

Condizente com o fortalecimento da discricionariedade técnica, com a melhor capacidade institucional da Administração Pública e com o diálogo interinstitucional entre o sistema de saúde e o de justiça, o Ministro Barroso sistematiza algumas premissas no RE 566.471 para orientar a distribuição de medicamentos de alto custo que comprometem o orçamento destinado à saúde de todos. Nesta sistematização, distinguem-se dois cenários, o das demandas requerendo medicamentos já incorporados pelo SUS e o das demandas com solicitação de medicamentos não incorporados. No primeiro cenário, com a dispensação gratuita de medicamento incorporado pelo SUS, a decisão é fácil, há direito subjetivo público à política de saúde e o Judiciário garante a efetivação da política pública estabelecida, desde que o paciente apresente de fato a necessidade da utilização daquela terapêutica requisitada e comprove a decisão denegatória administrativa de fornecer o medicamento previamente solicitado ou a demora para dispensá-lo. Verificou-se que não é inusitado que ações sejam propostas por desinformação sobre a disponibilização destes medicamentos, por desabastecimento, ou até a negativa de fornecimento, razão por que deve-se aplicar o Enunciado $\mathrm{n}^{\circ} 3 \mathrm{da}$ I Jornada de Direito à Saúde do CNJ com relação ao pedido administrativo prévio, de que cabe "ao autor da ação a busca preliminar sobre disponibilidade do atendimento, evitando-se a judicialização desnecessária".50

No segundo cenário, em que os medicamentos demandados não foram incorporados nas listas do SUS ou não há consenso, o voto sugere cinco requisitos cumulativos a serem seguidos pelo Poder Judiciário para redução e racionalização da judicialização e um parâmetro procedimental, que são:

(i) a incapacidade financeira do requerente para arcar com o custo correspondente, (ii) a demonstração de que a não incorporação do medicamento não resultou de decisão expressa dos órgãos competentes, (iii) a inexistência de substituto terapêutico incorporado pelo SUS, (iv) a comprovação de eficácia do medicamento pleiteado à luz da medicina baseada em evidências, e (v) a propositura da demanda necessariamente em face da União. Ademais, deve-se exigir a observância de 1 (um) parâmetro procedimental relativo à realização de diálogo interinstitucional entre o Poder Judiciário e entes ou pessoas com expertise técnica na área da saúde (e.g., câmaras e núcleos de apoio técnico em saúde no âmbito dos tribunais, profissionais do SUS e CONITEC), para fins de aferir a

50 Voto do Min. Roberto Barroso. BRASIL. Supremo Tribunal Federal. Tribunal Pleno. Recurso extraordinário n. 566.471. Relator: Ministro Marco Aurélio Mello. Pedido de vista do ministro Teori Zavascki suspendeu o julgamento no dia 28 de set. 2016. 
presença dos requisitos de dispensação e determinar aos órgãos competentes, no caso de deferimento judicial do medicamento, que avaliem a possibilidade de sua incorporação pelo SUS. 51

Para Barroso, o entabulamento de diálogo institucional entre o Poder Judiciário e entes ou pessoas com expertise técnica na área da saúde, confere ao magistrado a necessária visão da amplitude das questões relacionadas à demanda, de modo a considerar as razões da não incorporação de determinados medicamentos pelo SUS, se há alternativas terapêuticas para o tratamento e se existem provas científicas robustas da eficácia e segurança do fármaco requisitado. A tomada de decisão conta, assim, com o suporte das Câmaras de Assessoria Técnica e Núcleos de Apoio Técnico do Poder Judiciário (NAT-JUS), de profissionais de saúde integrantes do SUS, dos integrantes da Comissão Nacional de Incorporação de Tecnologias no SUS - CONITEC, além das razões do médico que prescreveu os medicamentos ou terapias postulados na demanda judicial.52

Quanto ao parâmetro procedimental de diálogo interinstitucional, o Ministro também dá o crédito às Jornadas de Direito da Saúde do CNJ, em conformidade ao Enunciado $n^{\circ}$ 18: "sempre que possível, as decisões liminares sobre saúde devem ser precedidas de notas de evidência científica emitidas por Núcleos de Apoio Técnico em Saúde - NATS", e ao Enunciado n 57: "em processo judicial no qual se pleiteia o fornecimento de medicamento, produto ou procedimento, é recomendável verificar se a questão foi apreciada pela Comissão Nacional de Incorporação de Tecnologias no SUS CONITEC". Outra das orientações importantes advindas dos Fóruns entre o CNJ e Ministério da Saúde, citados pelo ministro em seu voto, refere-se à implementação de banco de dados de informações técnicas subsidiando os magistrados na atividade judicante de acordo com termo de cooperação assinado em agosto de 2016.53

Em momento subsequente, se forem deferidos medicamentos que não estavam incorporados nas listas do SUS, o diálogo com os órgãos competentes (CONITEC e Ministério da Saúde) se mantém para que se possa viabilizar a incorporação dos novos fármacos, valendo-se da judicialização, desta feita com racionalidade e esforços combinados para o aperfeiçoamento da assistência farmacêutica para todos os demais pacientes que vierem a ter as mesmas necessidades, garantindo que o medicamento possa ser alcançado pela via administrativa e no contexto de negociação com os

\footnotetext{
51 Idem.

52 Idem.

53 Idem.
} 
fornecedores e poder público, em que se consegue reduzir valores na compra e promover a organização orçamentária futura. 54

Em suma, essa visão mais abrangente dos atores envolvidos na promoção do direito social à saúde e as alternativas encontradas para integrar o Poder Judiciário e demais órgãos administrativos competentes para o aprimoramento das decisões sobre o tema, permite concluir que o diálogo institucional encontra-se em pleno desenvolvimento na área da saúde. A prática dialógica da interação interinstitucional deve servir de modelo em outras áreas de grande complexidade que enfrentam graves problemas de inefetividade e omissão persistente quanto aos direitos sociais, tais como as questões referentes às políticas de moradia e à política carcerária no Brasil - áreas que exigem uma reestruturação geral e urgente.

\section{CONSIDERAÇÕES FINAIS}

A previsão da saúde nos arts. 60 e 196 da Constituição Federal de 1988 como um direito fundamental social impulsionou a judicialização da saúde e, pari passu, os diversos estudos doutrinários a respeito do fenômeno. Por se tratar de uma previsão genérica, em que as prestações correspondentes ao significado de "saúde" não estão especificadas no texto constitucional, uma parte considerável dos estudos realizados está centrada na própria possibilidade de judicialização dos direitos econômicos e sociais, tendo em vista a ausência de elementos normativos suficientes para amparar toda e qualquer pretensão. À medida que a saúde passou a ser reconhecida como um direito exigível do Estado, e as prestações correspondentes passaram a ser definidas e deferidas pela via judicial, outras incursões entraram em cena para analisar o fenômeno, buscando explicar as inevitáveis tensões causadas pela intervenção do Judiciário em questões que envolvem a distribuição de riqueza e bens da sociedade, que deveriam ser objeto de deliberação pelos representantes democraticamente eleitos pelo povo, e também nas reservas orçamentárias que, num contexto de escassez, se viam tumultuadas pela distribuição, paralela às políticas públicas, de medicamentos e tratamentos obtidos pela via judicial.

Diante da complexidade da questão, esses aspectos isoladamente considerados não esgotam problema da saúde, por muitos referido como "policêntrico", à medida que apresenta vários centros de decisão, vinculados a diferentes órgãos que compõem a estrutura estatal. Por tal razão, em vez de apontar uma instituição que possa/deva exercer posição de proeminência na questão, a questão da saúde implica o exame das formas de interação entre diversos órgãos que, dentro da capacidade institucional de cada um, cooperam para a otimização dos recursos que promovem o direito à saúde.

54 Idem. 
Nesse sentido, não se trata apenas de responder qual a instituição mais capaz para decidir sobre a questão, mas de integrar e potencializar as diversas instituições encarregadas das diversas facetas do problema, na medida de suas capacidades. Por isso, a teoria do diálogo institucional pode justificar e explicar adequadamente o quadro hoje vigente na área da saúde. Inicialmente introduzida no âmbito da doutrina de direito constitucional, conquistou seu espaço na fundamentação de decisões judiciais e, o mais importante, na coordenação de ações dentro do próprio Poder Judiciário, que se mostrou aberto a (e necessitado de) aportes oriundos dos órgãos técnicos envolvidos na área da saúde, que são as instâncias responsáveis pelos debates que implicam o conhecimento de protocolos científicos concernentes à ciência médica e farmacêutica. Desse modo, aquilo que parecia uma tendência na jurisprudência do STF está se consolidando no plano jurídico e também na realidade: o Poder Judiciário reconhece a necessidade de diálogo com as demais instituições responsáveis pela efetivação da saúde.

O objetivo deste estudo era demonstrar a complexidade da área da saúde, dos interesses presentes nesse mercado, além de propor uma discussão sobre o desenho institucional para atender àquela complexidade, refletindo sobre práticas adotadas na administração da justiça. Como visto, para além da jurisprudência e das experiências inclusivas da área técnica nos litígios judiciais, os procedimentos dialógicos começam a ser efetivamente empregados na tutela judicial do direito à saúde.

Embora não se deseje aprofundar o fundamento filosófico que justifica a preferência por esta alternativa de diálogo em face da adoção de um estado constitucional democrático - até para não tornar este texto mais longo do que o necessário -, não se deve abstrair o fato de que a ampla participação dos vários atores otimiza a capacidade do Judiciário de "enriquecer a qualidade argumentativa numa democracia".55 Esta linha de pensamento atenta ao fato de que a legitimação democrática do ponto de vista formal deve se alinhar à legitimação material, importando para isso a avaliação do conteúdo das decisões tomadas. 56 O processo deliberativo entre múltiplos atores na tomada de decisões se apresenta, deste modo, como um valor fundamental para conferir legitimidade às decisões judiciais concernentes aos atos dos demais poderes. 57 A postura dialógica enfatiza, pois, a importância da ação comunicativa num regime democrático, traduzindo cabalmente aquilo que Hans Kelsen,58 de longa data, já dizia: "democracia é discussão".

\footnotetext{
55 MENDES, Conrado Hübner. Direitos Fundamentais, separação de poderes e deliberação. São Paulo: Saraiva, 2011. p. 2728.

56 STRECK, Lênio Luiz. Jurisdição Constitucional e Decisão Jurídica. 4. ed. São Paulo: RT, 2014. p. 158 e ss.

57 VAN HOECKE, Mark. Judicial review and deliberative democracy: a circular model of law creation and legitimation. Ratio Juris, v. 14, n. 4, p. 415-423, dez. 2001. p. 418.

58 KELSEN, Hans. Fundamentos da democracia. In: KELSEN, Hans. A Democracia. 2.ed. São Paulo: Martins Fontes, 2000. p. 241.
} 


\section{REFERÊNCIAS}

AMARAL, Gustavo. Direito, escassez e escolha: em busca de critérios jurídicos para lidar com a escassez de recursos e as decisões trágicas. Rio de Janeiro: Renovar, 2001.

ANGELL, Márcia. A verdade sobre os laboratórios farmacêuticos. 2. ed. Rio de Janeiro: Record, 2007.

AVILA, Ana Paula O.; MIRANDA, Paula Mandagará. Supremo Tribunal Federal: ativismo ou self-restraint na efetivação de direitos sociais? Quaestio luris, Rio de Janeiro, v. 10, p. 519-543, 2017.

ÁVILA, Humberto. "Neoconstitucionalismo": Entre a "ciência do direito" e o "direito da ciência". Revista Eletrônica de Direito do Estado, n. 17. jan./mar. 2009.

BARCELLOS, Ana Paula de. Constitucionalização das políticas públicas em matéria de direitos fundamentais: o controle político-social e o controle jurídico no espaço democrático. In: SARLET, Ingo (org.). Direitos fundamentais, orçamento e "reserva do possível". Porto Alegre: Livraria do Advogado Editora, 2008.

BARREIRO, Guilherme Scodeler de Souza; FURTADO, Renata Pedretti Morais. Inserindo a judicialização no ciclo das políticas públicas. Revista de Administração Pública, v. 49, n. 2, p. 293-314; mar./abr. 2015.

BARROSO, Luís Roberto. 0 controle de Constitucionalidade no Direito Brasileiro. 4. ed. São Paulo: Saraiva, 2009.

BRANDÃO, Rodrigo. Supremacia judicial versus diálogos constitucionais: a quem cabe a última palavra sobre o sentido da constituição? Rio de Janeiro: Lumen Juris, 2012.

BRASIL. Ministério da Saúde. Secretaria de Vigilância em Saúde. Programa Nacional de DST e Aids. O Remédio via Justiça: Um estudo sobre o acesso a novos medicamentos e exames em HIV/aids no Brasil por meio de ações judiciais / Ministério da Saúde, Secretaria de Vigilância em Saúde, Programa Nacional de DST e Aids. Brasília: Ministério da Saúde. 2006. P. 186. Disponível em: <http:// bvsms.saude.gov.br/bvs/publicacoes/medic_justica01.pdf >. Acesso em 18 de setembro de 2016.

BRASIL. Ministério da Saúde. Secretaria de Vigilância em Saúde. Departamento de Vigilância das Doenças Transmissíveis. Talidomida: orientação para o uso controlado. Brasília: Ministério da Saúde, 2014.

BRASIL. Conselho Nacional de Justiça. Recomendação n. 31 de 30/3/2010. Disponível em: <http://www.cnj.jus.br/images/atos_normativos/recomendacao/recomendacao_31_30032010_22102012173049.pdf>. Acesso em 9 de out. 2016.

CAPPELLETTI, Mauro. Juízes Legisladores?. Trad. Carlos Alberto A. de Oliveira. Porto Alegre: Sergio Antonio Fabris Editor, 1993. 
CLÈVE, Clèmerson Merlin; LORENZETTO, Bruno Meneses. Teorias Interpretativas, Capacidades Institucionais e Crítica. Revista Direitos Fundamentais \& Democracia, Curitiba, v. 19, n. 19, p. 131-168, jan./jun. 2016.

COSTA, Ediná Alves. Vigilância Sanitária, desafios à construção de um sistema nacional para a proteção da saúde. In: NOBRE, Milton Augusto de Brito; SILVA, Ricardo Augusto Dias da (Coords.). 0 CNJ e os desafios da efetivação do direito à saúde. 2 ed. Belo Horizonte: Fórum, 2013.

COSTA, Rafael de Oliveira. Entre o Direito, a Política e a Economia: (re)construindo a análise institucional comparativa. Revista da Faculdade de Direito - UFPR, Curitiba, vol. 59, n. 2, p. 75-90, 2014.

DUQUE, Marcelo Schenk. Direito privado e constituição: Drittwirkung dos direitos fundamentais, construção de um modelo de convergência à luz dos contratos de consumo. São Paulo: Revista dos Tribunais, 2013.

FUCHS, Flávio Danni. Terapêutica na Prática Clínica cardiovascular: Vivências e Evidência. Arq. Bras. Cardiol. , São Paulo, v. 85, n. 1, p. 72-75, Julho de 2005. Disponível em: <http:// www.scielo.br/scielo.php?script=sci_arttext\&pid=S0066-782X2005001400015\&lng=en\&nrm=iso>. Acesso em 27 de outubro de 2016.

FUCHS, Flávio Danni; WANNMACHER, Lenita; FERREIRA, Maria Beatriz Cardoso. Farmacologia Clínica: fundamentos da terapêutica racional. 3. ed. Rio de Janeiro: Guanabara Koogan, 2006.

GOLDIM, José Roberto. O uso de drogas ainda experimentais em assistência: extensão de pesquisa, uso compassivo e acesso expandido. Rev Panam Salud Publica, Washington , v. 23, n. 3, p. 198-206, Mar. 2008. Disponível em: <http://www.scielosp.org/scielo.php?script=sci_arttext\&pid=S1020-49892008000300007\&lng=en\&nrm=iso >. Acesso em 19 Out. 2016.

KELSEN, Hans. Fundamentos da democracia. In: KELSEN, Hans. A Democracia. 2.ed. São Paulo: Martins Fontes, 2000.

KOMESAR, Neil F. Taking Institutions Seriously: introduction to a strategy for constitutional analysis. The University of Chicago Law Review, Chicago, vol. 51, n. 2, p. 366-446, mar./may 1984.

KOMESAR, Neil F. A job for the judges: the Judiciary and the Constitution in a massive and complex society. Michigan Law Review, vol. 86, p. 657-721, 1988.

KOMESAR, Neil F. Law's Limits: the Rule of Law and the supply and demand of Rights. New York: Cambridge University Press, 2001.

MACHADO, Marina Amaral de Ávila et al . Judicialização do acesso a medicamentos no Estado de Minas Gerais, Brasil. Rev. Saúde Pública, São Paulo, v. 45, n. 3, p. 590598, jun. 2011. Disponível em <http://www.scielo.br/scielo.php?script=sci_arttext\&pid=S0034-89102011000300018\&lng=en\&nrm=iso >. Acesso em 21 Abril de 2016. 
MEDEIROS, Marcelo; DINIZ, Debora; SCHWARTZ, Ida Vanessa Doederlein. A tese da judicialização da saúde pelas elites: os medicamentos para mucopolissacaridose. Ciênc. saúde coletiva, Rio de Janeiro, v. 18, n. 4, p. 1079-1088, Apr. 2013. Disponível em <http://www.scielo.br/scielo.php?script=sci_arttext\&pid=S1413-81232013000400022\&lng=en\&nrm=iso $>$. Acesso em 21 Abril de 2016.

MELLO, Claudio Ari. Democracia constitucional e direitos fundamentais. Porto Alegre: Livraria do Advogado Editora, 2004.

MENDES, Conrado Hübner. Direitos Fundamentais, separação de poderes e deliberação. São Paulo: Saraiva, 2011.

OLIVEIRA, Luciano Moreira de. Análise da relação entre laboratórios farmacêuticos e médicos do Sistema Único de Saúde à luz do princípio da moralidade administrativa. Revista de Informação Legislativa, Brasília, vol. 52, n. 205, jan./mar. 2015. Disponível em: <http://www2.senado.gov.br/ bdsf/item/id/509950>. Acesso em: 20 de ago.de 2016.

PEREIRA, Jane Reis Gonçalves. Direitos sociais, Estado de Direito e desigualdade: reflexões sobre as críticas à judicialização dos direitos prestacionais. Quaestio Juris, Rio de Janeiro, vol. 8, n. 3, 2015. DOI: http://dx.doi.org/1012957/rqi.2015.

QUINTAS, Fábio Lima. Juízes-administradores, a intervenção judicial na efetivação dos direitos sociais. Revista de Informação Legislativa, Brasília, ano 53, n. 209, mar. 2016.

RAMOS, Elival da Silva. O direito à saúde em face da discricionariedade administrativa. In: MARQUES NETO, Floriano de Azevedo (coord.). Direito e administração pública: estudos em homenagem a Maria Sylvia Zanella Di Pietro. São Paulo: Atlas, 2013.

RIBEIRO, Diógenes V. Hassan. Judicialização e Desjudicialização: entre a deficiência do legislativo e a insuficiência do judiciário. Revista de Informação Legislativa, Brasília, v. 50, n. 199, p. 25-33, jul./set. 2013. Disponível em: <http://www2.senado.gov.br/bdsf/item/id/502916>. Acesso em: 11 de mai. 2016.

SARTORI JUNIOR, Dailor et al . Judicialização do acesso ao tratamento de doenças genéticas raras: a doença de Fabry no Rio Grande do Sul. Ciênc. Saúde Coletiva, Rio de Janeiro, v. 17, n. 10, p. 2717-2728, Out. 2012. Disponível em: <http://www.scielo.br/scielo.php?script=sci_arttext\&pi$\mathrm{d}=\mathrm{S} 1413-81232012001000020 \&$ Ing=en\&nrm=iso >. Acesso em: 27 Out. 2016.

STRECK, Lênio Luiz. O que é isto, o ativismo judicial, em números? Os constitucionalistas. Publicação digital, 26 out. 2013. Disponível em: <http://www.osconstitucionalistas.com.br/o-que-e-isto-o-ativismo-judicial-em-numeros>. Acesso em 2 set. 2016.

STRECK, Lênio Luiz. Jurisdição Constitucional e Decisão Jurídica. 4. ed. São Paulo: RT, 2014. 
VALLE, Vanice Regina Lírio do. Políticas públicas, direitos fundamentais e controle judicial. 2. ed. rev. ampl. e atual. Belo Horizonte: Editora Fórum, 2016.

VAN HOECKE, Mark. Judicial review and deliberative democracy: a circular model of law creation and legitimation. Ratio Juris, v. 14, n. 4, p. 415-423, dez. 2001.

WANG, Daniel Wei L.; VASCONCELOS, Natália Pires de. Adjudicação de direitos e escolhas políticas na assistência social: o STF e o critério da renda do PBC. Novos Estudos, vol. 3, p. 135-151, nov. 2015. 